\title{
PERSPEKTIF GENDER PADA MASYARAKAT SUNDA \\ DI DESA CIKUNIR KECAMATAN SINGAPARNA KABUPATEN TASIKMALAYA TAHUN 2013
}

\author{
Oleh: \\ Santi Susanti, S.SiT, M.Kes
}

\begin{abstract}
A. Abstrak
Latar Belakang. Kesetaraan gender bukan melulu mengenai perempuan tetapi mengenai perempuan dan laki-laki. Dalam banyak hal perempuan di Indonesia telah mencapai kemajuan pesat, meskipun masih cukup jauh dari pencapaian kesetaraan gender. Hal tersebut dapat dilihat dari hasil pencapaian tujuan Pembangunan Millenium Development Goals (MDGs) yang ke-3 khususnya dalam mencapai tujuan lapangan pekerjaan dan keterwakilan dalam parlemen yang dimiliki perempuan Indonesia masih kurang. Tujuan dari penelitian ini adalah untuk mendapatkan gambaran perspektif gender masyarakat sunda wilayah Desa Cikunir pada tahun 2013.
\end{abstract}

Metode Penelitian. Jenis Penelitian yang digunakan adalah penelitian kuantitatif dengan pendekatan deskriptif. Populasi dalam penelitian ini adalah Pasangan Usia Subur (PUS) di Wilayah Desa Cikunir Periode Maret s.d Mei 2013 dengan jumlah PUS adalah 1348. Tekhnik sampel menggunakan sratified random sampling dengan menggunakan dusun sebagai strata. Besar sampel menggunakan tabel krecjie dengan taraf signifikan 5\% maka besar sampel diperoleh 299 sampel. Analisis data menggunakan analisis univariat.

Hasil penelitian diketahui bahwa perspektif gender masyarakat sunda di Desa Cikunir Kecamatan Singaparna Kabupaten Tasikmalaya sebagian besar berperspektif positif (53\%). Meskipun demikian tidak dapat dipandang sebelah mata meskipun hanya sebagian kecil yang berperspektif negatif (47\%) . Penempatan perempuan yang tidak seimbang akan menciptakan ketidakharmonisan dalam membina kehidupan rumah tangga dan masyarakat.

Saran. Hendaknya Suami Istri dapat proaktif dalam mencari informasi tentang gender dapat melalui televisi, radio, koran, tokoh agama atau petugas kesehatan di puskesmas, suami/istri hendaknya dapat saling menghormati hak dan kewajiban satu dengan yang lainnya, suami/istri hendaknya bertanggungjawab bersama-sama dalam membangun keharmonisan dan kesejahteraan keluarga

\section{Kata Kunci : Gender, Perspektif, Pasangan Usia Subur}

\section{B. Pendahuluan}

Kesetaraan gender bukan melulu mengenai perempuan tetapi mengenai perempuan dan laki-laki. Dalam banyak hal perempuan di Indonesia telah mencapai kemajuan pesat, meskipun masih cukup jauh dari pencapaian kesetaraan gender. Hal tersebut dapat dilihat dari hasil pencapaian tujuan Pembangunan Millenium Development Goals (MDGs) yang ke-3 yaitu Mendorong kesetaraan Gender dan Pemberdayaan Perempuan. Tujuan MDGS ke-3 
memiliki 3 target yaitu pendidikan, lapangan pekerjaan dan keterwakilan dalam parlemen. Untuk tujuan pertama Indonesia cukup berhasil, namun dalam mencapai tujuan kedua dan ketiga kesempatan yang dimiliki perempuan Indonesia masih kurang (Stalker., 2008).

Dalam sejarah banyak agama dan peradaban yang masih terkonstruksi dalam paham patriakhi, pendidikan dianggap sebagai faktor yang mempengaruhi terjadinya mobilitas sosial dimana peningkatan status perempuan akibat pendidikan akan mengintervensi atau turut campur tangan dengan urusan publik. Hal inilah yang menyebabkan perempuan terkungkung dalam beban-beban domestik. Sementara saat perempuan harus tampil membantu perekonomian keluarga kesempatan kerja yang didapat sangat terbatas karena pendidikannya rendah. (Asriani, 2010).

Selain kurang mendapatkan perkerjaan, perempuan juga cenderung mendapatkan pekerjaan tidak sebaik laki-laki. Di pabrik-pabrik indutri tekstil banyak perempuan muda yang bekerja dengan upah rendah seringkali dengan penyelia laki-laki. Demikian pula halnya di pemerintahan. Perempuan hanya menduduki $9,6 \%$ jabatan tinggi dalam birokrasi pemerintahan. Perempuan juga kurang terwakili dibidang politik (Stalker., 2008).

Membincang gender dewasa ini akan senantiasa berkaitan erat dengan perkembangan gerakan emansipasi perempuan di hampir seluruh belahan dunia. Gender bukan hanya menyoal masalah sosial, akan tetapi ekonomi, politik, dan dimensi lainnya. Di Indonesia, perjuangan kesetaraan gender seiring sejalan dengan perkembangan paham demokrasi. Relevansinya terletak pada substansi demokrasi yang menghendaki setiap proses kebijakan yang adil, tanpa pandang bulu sehingga setiap orang bisa berpartispasi aktif dalam pembangunan, baik laki-laki maupun perempuan.

Gambaran

ketertinggalan perempuan menunjukkan bahwasanya kebijakan pemerintah dalam kebijakan gender masih belum masif. Meskipun diskursus gender banyak diklaim telah membuahkan hasil bagi perempuan jika melihat institusionalisasi kebijakan pro perempuan, fakta dilapangan masih menunjukkan diskriminasi terhadap perempuan. Hal ini bisa dibuktikan dengan presentasi kesenjangan gender yang tercatat di region lebih kecil seperti kabupaten atau kota.

Kabupaten Tasikmalaya misalnya. Dengan wilayah seluas 2.712,49 Km, Kabupaten Tasikmalaya memiliki catatan peningkatan AKI pada tahun 2011 dibandingkan tahun 2010. Menurut data Binkesmas, untuk tahun 2011, kematian ibu maternal yang terdiri atas, kematian ibu saat hamil berjumlah 11 orang $(20,37 \%)$, kematian ibu bersalin 23 orang $(42,59 \%)$, kematian ibu nifas 20 orang $(37,04 \%)$

Sebagai kota yang dikenal dengan kota santri, kepadatan penduduk tertinggi Kabupaten Tasikmalaya berada di wilayah Singaparna. Salah satu desa yang berada diwilayah Singaparna adalah Cikunir. Desa Cikunir pada tahun 2012 memiliki jumlah penduduk 8.816 dengan komposisi 3.676 laki-laki dan 5140 perempuan. Dengan mayoritas penduduk perempuan, sebenarnya desa Cikunir memiliki asset yang sangat berharga jika saja mampu 
memberdayakan para perempuannya. menunjukkan kemiskinan sebagai persoalan yang belum mampu menemukan jalan keluarnya. Sebesar $27 \%$ dari 2.557 kepala keluarga masih berada dibawah garis kemiskinan dengan total 2.299 orang menganggur. Pendapatan perkeluarga rata-rata berkisar antara Rp 700.000,00 - Rp $800.000,00$ perbulan.

Proses subordinasi perempuan dalam kisaran angka Nasional yang disebutkan diatas sebelumnya, nampak jelas pada representasi angka perempuan bekerja di Desa Cikunir yang hanya berjumlah 400 orang, seperlima lebih kecil dari jumlah perempuan yang tidak bekerja. Mayoritas perempuan adalah Ibu

\section{Metode Penelitian}

Jenis Penelitian yang digunakan adalah penelitian kuantitatif dengan pendekatan deskriptif. Populasi dalam penelitian ini adalah Pasangan Usia Subur (PUS) di Wilayah Desa Cikunir Periode Maret s.d Mei 2013 dengan jumlah PUS adalah 1348. Tekhnik sampel menggunakan sratified random sampling dengan menggunakan dusun sebagai strata. Besar sampel menggunakan tabel krecjie dengan pupulasi 1348, dengan taraf signifikan 5\% maka besar sampel diperoleh 299 sampel. Dengan demikian jumlah sampel untuk masing-masing dusun adalah sebagai berikut : Dusun Sumul agung 16 , Banjarsari 44, Sunia 15, Margamulya 21, Gunung Panghulu 9,
Namun fakta dilapangan masih Rumah Tangga dan menghabiskan sebagian besar waktunya di rumah saat suami mereka bekerja. Sebagian Ibu Rumah Tangga tersebut ada yang membantu suaminya untuk menambah penghasilan dengan melakukan pekerjaan Industri rumah seperti menganyam bambu, membuat tas dari bahan baku sampah plastik, dsb.

Berpijak dari permasalahan tersebut diatas, peneliti mencoba menggali perspektif gender warga desa Cikunir sebagai bagian dari upaya pemberdayaan perempuan dalam rangka berpartisipasi aktif membantu pemerintah untuk mencapai goal MDGs 2015 mendatang.

Cilaja 22 orang, Gunung Kasur 24, Pamengpeuk 19, Anggaraja 29, Burahol 15, Gunung Heulang 20, Cihandeuleum 33, Perum 13, Legok 19 sampel.

Pengumpulan Data dilakukan dengan menyebarkan kuesioner kepada responden penelitian. Pendistribusian kuesioner kepada responden dibantu oleh tim penelitian yang terdiri dari 5 orang tim. Ketua peneliti melaksanakan pertemuan koordinasi dengan anggota tim untuk persamaan persepsi tekhnik dalam pengambilan data pada responden. Analisis data hasil penelitian dilakukan dengan analisis univariat untuk menentukan proporsi terkait dengan perspektif gender pada masyarakat sunda di desa Cikunir. 


\section{Hasil Penelitian}

\section{a. Karakteristik Responden}

1) Umur Responden

Tabel 2.1

Gambaran umur responden

\begin{tabular}{|c|c|c|c|c|c|}
\hline Umur & $\mathrm{N}$ & Minimum & Maximum & Mean & SD \\
\hline & 300 & 19 & 70 & 35,43 & 8,005 \\
\hline
\end{tabular}

Berdasarkan tabel 2.1 bahwa umur responden minimum 19 tahun dan maksimum 70 tahun. Usia rata-rata responden adalah 35 tahun.

2) Pendidikan Responden

Gambaran umum pendidikan responden dapat dilihat pada tabel 2.2 sebagai berikut :

Tabel 2.2

Distribusi Frekuensi Tingkat Pendidikan Repsonden

\begin{tabular}{|l|l|l|}
\hline Pendidikan & Frekuensi & Persentase \\
\hline SD & 123 & 41 \\
\hline SMP & 77 & 26 \\
\hline SMA & 84 & 28 \\
\hline PT & 16 & 5 \\
\hline Jumlah & 300 & 100 \\
\hline
\end{tabular}

Berdasarkan tabel 2.2 diketahui bahwa tingkat pendidikan responden paling banyak lulusan SD yaitu $41 \%$ dan paling sedikit adalah lulusan Perguruan Tinggi yaitu 5\%.

3) Pekerjaan Responden

Gambaran pekerjaan responden dapat dilihat pada tabel 2.3 sebagai berikut :

Tabel 2.3

Distribusi Frekuensi Tingkat Pekerjaan Responden

\begin{tabular}{|l|l|l|}
\hline Pekerjaan & Frekuensi & Persentase \\
\hline Buruh & 9 & 3 \\
\hline IRT & 260 & 87 \\
\hline Karyawan & 4 & 1 \\
\hline PNS & 10 & 3 \\
\hline Wiraswasta & 17 & 6 \\
\hline Jumlah & 300 & 100 \\
\hline
\end{tabular}

Berdasarkan tabel 2.3 tingkat pekerjaan responden sebagian besar adalah sebagai Ibu Rumah Tangga yaitu $87 \%$.

\section{b. Perspektif Gender}

Berdasarkan hasil penelitian diperoleh data perspektif gender masyarakat sunda desa Cikunir Kabupaten Tasikmalaya sebagai berikut :Tabel 2.4

Distribusi Frekuensi Perspektif Gender Masyarakat Sunda

Desa Cikunir Kabupaten Tasikmalaya Tahun 2013 


\begin{tabular}{|l|c|c|}
\hline Perspektif Gender & Frekuensi & Persentase (\%) \\
\hline Positif $(\geq 83)$ & 159 & 53 \\
\hline Negatif $(<83)$ & 141 & 47 \\
\hline Jumlah & 300 & 100 \\
\hline
\end{tabular}

Hasil penelitian menunjukkan bahwa perspektif gender masyarakat sunda di

Desa Cikunir sebagian besar dalam kategori positif yaitu 53\%.

Tabel 2.5

Distribusi Frekuensi Kuesioner Perspektif Gender Masyarakat Sunda

Desa Cikunir Kabupaten Tasikmalaya Tahun 2013

\begin{tabular}{|l|l|c|c|c|c|c|c|c|c|}
\hline No & \multicolumn{1}{|c|}{ Perspektif Gender } & \multicolumn{5}{c|}{ Frekuensi } & \multicolumn{3}{c|}{ Persentase (\%) } \\
\hline & \multicolumn{1}{|c|}{ SS } & S & TS & STS & SS & S & TS & STS \\
\hline 1 & Laki-laki adalah pemimpin & 214 & 80 & 0 & 6 & 71 & 27 & 0 & 2 \\
\hline 2 & $\begin{array}{l}\text { Perempuan tidak perlu } \\
\text { berpendidikan tinggi }\end{array}$ & 9 & 17 & 210 & 64 & 3 & 6 & 70 & 21 \\
\hline 3 & $\begin{array}{l}\text { Suami adalah pengambil } \\
\text { keputusan dalam keluarga }\end{array}$ & 83 & 174 & 42 & 1 & 28 & 58 & 14 & 3 \\
\hline 4 & $\begin{array}{l}\text { Perempuan menggunakan } \\
\text { perasaan dalam setiap } \\
\text { tindakan sehingga tidak } \\
\text { rasional }\end{array}$ & 24 & 75 & 192 & 9 & 8 & 25 & 64 & 3 \\
\hline 5 & $\begin{array}{l}\text { Urusan dapur hanya urusan } \\
\text { perempuan saja }\end{array}$ & 11 & 50 & 208 & 31 & 4 & 17 & 69 & 10 \\
\hline 6 & $\begin{array}{l}\text { Laki-laki dan perempuan } \\
\text { memiliki kedudukan yang } \\
\text { sama }\end{array}$ & 99 & 148 & 53 & 0 & 33 & 49 & 18 & 0 \\
\hline 7 & $\begin{array}{l}\text { Urusan rumah tangga } \\
\text { tanggungjawab berdua } \\
\text { antara suami dan istri }\end{array}$ & 173 & 120 & 7 & 0 & 58 & 40 & 2 & 0 \\
\hline 8 & $\begin{array}{l}\text { Suami bertanggungjawab } \\
\text { untuk membesarkan anak } \\
\text { dalam keluarga }\end{array}$ & 98 & 164 & 33 & 5 & 33 & 55 & 11 & 2 \\
\hline 9 & $\begin{array}{l}\text { Istri bertanggungjawab } \\
\text { untuk membesarkan anak } \\
\text { dalam keluarga }\end{array}$ & 12 & 37 & 155 & 95 & 4 & 12 & 52 & 32 \\
\hline 10 & $\begin{array}{l}\text { Perempuan urusan dalam } \\
\text { rumah saja }\end{array}$ & 26 & 31 & 222 & 21 & 9 & 10 & 74 & 7 \\
\hline 11 & $\begin{array}{l}\text { Laki-laki pencari nafkah } \\
\text { utama dalam keluarga }\end{array}$ & 209 & 82 & 8 & 1 & 70 & 27 & 3 & 0,3 \\
\hline 12 & $\begin{array}{l}\text { Istri harus melayani } \\
\text { kebutuhan suami }\end{array}$ & 113 & 168 & 19 & 0 & 38 & 56 & 6 & 0 \\
\hline 13 & $\begin{array}{l}\text { Istri harus seizin suami jika } \\
\text { hendak bepergian, suami } \\
\text { tidak memerlukan izin }\end{array}$ & 74 & 48 & 171 & 7 & 25 & 16 & 57 & 2 \\
\hline 14 & Pilihan jenis KB ditentukan & 8 & 77 & 206 & 9 & 3 & 26 & 69 & 3 \\
\hline & & & & & & & & & \\
\hline
\end{tabular}




\begin{tabular}{|c|c|c|c|c|c|c|c|c|c|}
\hline & oleh keputusan suami & & & & & & & & \\
\hline 15 & $\begin{array}{l}\text { Menjaga kebersihan rumah } \\
\text { adalah tanggung jawab } \\
\text { bersama }\end{array}$ & 168 & 128 & 4 & 0 & 56 & 43 & 1 & 0 \\
\hline 16 & $\begin{array}{l}\text { Suami memberikan } \\
\text { kebebasan kepada istri } \\
\text { untuk bekerja }\end{array}$ & 81 & 182 & 34 & 3 & 27 & 61 & 11 & 1 \\
\hline 17 & $\begin{array}{l}\text { Suami tidak melakukan } \\
\text { Kekerasan Dalam Rumah } \\
\text { Tangga kepada Istri }\end{array}$ & 222 & 74 & 2 & 2 & 74 & 25 & 0,7 & 0,7 \\
\hline 18 & $\begin{array}{l}\text { Seorang ayah tidak } \\
\text { membeda-bedakan } \\
\text { kesempatan pendidikan } \\
\text { untuk putra atau putri } \\
\text { mereka }\end{array}$ & 237 & 63 & 0 & 0 & 79 & 21 & 0 & 0 \\
\hline 19 & $\begin{array}{l}\text { Pengambil keputusan } \\
\text { keluarga tidak harus suami }\end{array}$ & 134 & 135 & 31 & 0 & 45 & 45 & 10 & 0 \\
\hline 20 & $\begin{array}{l}\text { Laki-laki tidak boleh } \\
\text { menangis }\end{array}$ & 34 & 161 & 85 & 20 & 11 & 54 & 28 & 7 \\
\hline 21 & $\begin{array}{l}\text { Suami bekerjasama dengan } \\
\text { istri untuk membersihkan } \\
\text { rumah }\end{array}$ & 159 & 121 & 15 & 5 & 53 & 40 & 5 & 2 \\
\hline 22 & $\begin{array}{l}\text { Laki-laki tidak cocok } \\
\text { bekerja sebagai sekretaris }\end{array}$ & 21 & 94 & 171 & 13 & 7 & 31 & 57 & 4 \\
\hline 23 & $\begin{array}{l}\text { Perempuan mampu untuk } \\
\text { menjadi presiden }\end{array}$ & 112 & 132 & 49 & 7 & 37 & 44 & 16 & 2 \\
\hline 24 & $\begin{array}{l}\text { Istri sebagai pencari nafkah } \\
\text { tambahan keluarga }\end{array}$ & 107 & 153 & 25 & 15 & 36 & 51 & 8,3 & 5 \\
\hline 25 & $\begin{array}{l}\text { Laki-laki kuat, perempuan } \\
\text { lemah }\end{array}$ & 12 & 41 & 181 & 66 & 4 & 14 & 60 & 22 \\
\hline 26 & Laki-laki memasak di dapur & 55 & 104 & 130 & 11 & 18 & 34 & 43 & 4 \\
\hline 27 & $\begin{array}{l}\text { Keputusan hamil atau tidak } \\
\text { hamil ditentukan oleh } \\
\text { keputusan suami }\end{array}$ & 30 & 50 & 198 & 22 & 10 & 17 & 66 & 7 \\
\hline 28 & $\begin{array}{l}\text { Istri berhak untuk menolak } \\
\text { berhubungan badan dengan } \\
\text { suami }\end{array}$ & 45 & 141 & 89 & 25 & 15 & 47 & 30 & 8 \\
\hline 29 & $\begin{array}{l}\text { Istri bisa aktif dalam } \\
\text { berbagai kegiatan sosial di } \\
\text { masyarakat }\end{array}$ & 158 & 138 & 2 & 2 & 53 & 46 & 0,7 & 0,7 \\
\hline 30 & $\begin{array}{l}\text { Keuputusan dalam keluarga } \\
\text { dilakukan melalui } \\
\text { musyawarah mufakat suami } \\
\text { dan istri }\end{array}$ & 258 & 42 & 0 & 0 & 86 & 14 & 0 & 0 \\
\hline
\end{tabular}


Berdasarkan tabel 1.5 perspektif responden tentang gender masih terdapat beberapa konsep yang bias gender seperti pada pertanyaan nomor 1 sebagian besar responden sangat setuju laki-laki sebagai pemimpin (71\%). Pertanyaan nomor 3 sebagian besar responden setuju suami adalah pengambil keputusan dalam keluarga (53\%). Pertanyaan nomor 11, $70 \%$ responden sangat setuju Laki-laki pencari nafkah utama dalam keluarga.

\section{E. Pembahasan}

Berdasarkan hasil penelitian menunjukkan bahwa perspektif gender masyarakat sunda di Desa Cikunir sebagian besar dalam kategori positif yaitu 53\%. Data tersebut berdampak posistif terhadap peran perempuan di Desa Cikunir. Gender adalah konsep yang mengacu pada pembedaan peran dan tanggungjawab laki-laki dan perempuan yang terjadi akibat dari dan dapat berubah oleh keadaan sosial dan budaya masyarakat. Kesetaraan dan keadilan gender suatu kondisi dimana porsi dan siklus sosial perempuan dan laki-laki setara, serasi, seimbang dan harmonis. Kondisi ini dapat terwujud apabila terdapat perlakuan adil antara perempuan dan laki-laki. Penerapan kesetaraan dan keadilan gender harus memperhatikan masalah kontekstual dan situasional, bukan berdasarkan perhitungan matematik dan tidak bersifat universal. Pandangan ini membedakan sekurang-kurangnya 3 konteks kehidupan seseorang dalam keluarga, masyarakat dan agama.

Untuk mewujudkan relasi gender yang berkeadilan sedapat mungkin menghilangkan kesenjangan hubungan dan pembagian kerja antara laki-laki dan perempuan dalam
Pertanyaan nomor 12 Istri harus melayani kebutuhan suami 56\% responden setuju. Pertanyaan nomor 20 Laki-laki tidak boleh menangis $54 \%$ setuju. Pertanyaan nomr 24 sebagian besar responden setuju Istri sebagai pencari nafkah tambahan keluarga (51\%). Pertanyaan nomor 26 $43 \%$ responden tidak setuju Laki-laki memasak di dapur.

berbagai bidang kehidupan dengan memperhatikan kodrat, harkat dan martabatnya. Kesetaraan gender (gender equity) adalah suatu proses yang ditempuh untuk menghantarkan laki-laki dan perempuan secara dinamis memperoleh akses, partisipasi, kontrol dan manfaat dalam aktifitas kehidupan baik dalam keluarga, masyarakat maupuan berbangsa dan bernegara. Untuk itu diperlukan upaya untuk memperbaiki kondisi secara kualitas maupun kemampuan bagi kelompok yang tertinggal baik perempuan maupun laki-laki melalui affirmative action. (Mufidah, CH, 2004)

$\begin{array}{lcr}\begin{array}{c}\text { Kesetaraan } \\ \text { menghasilkan } \\ \text { "deviden }\end{array} & \begin{array}{r}\text { akan } \\ \text { ganda". }\end{array} \\ \text { berempuan } & \text { yang } & \text { sehat, }\end{array}$ memiliki anak-anak perempuan dan laki-laki yang sehat, berpendidikan dan percaya diri. Pengaruh besar permpuan dalam keluarga telah memperlihatkan dampak yang positif pada gizi, perawatan kesehatan dan pendidikan anak-anak mereka. (Widaningsih, 2007)

Walaupun demikian masih terdapat beberapa konsep yang bias gender hal tersebut dapat dilihat dari jawaban responden terhadap beberapa pertanyaan yang diajukan dalam 
kuesioner. Sebagian besar responden sangat setuju laki-laki sebagai pemimpin $(71 \%)$. Sebagian besar responden setuju suami adalah pengambil keputusan dalam keluarga (53\%). Pertanyaan nomor 11 dengan $70 \%$ responden sangat setuju laki-laki pencari nafkah utama dalam keluarga. Lima Puluh Enam Persen (56\%) responden setuju istri harus melayani kebutuhan suami. 54\% responden setuju laki-laki tidak boleh menangis. Sebagian besar responden setuju Istri sebagai pencari nafkah tambahan keluarga $(51 \%)$. Dan $43 \%$ responden tidak setuju Laki-laki memasak di dapur. Kondisi tersebut peneliti cermati kemungkinan berkaitan dengan tingkat pendidikan responden yang sebagian besar adalah Sekolah Dasar (SD) (41\%) dan sebagian besar dari mereka adalah sebagai Ibu Rumah Tangga yaitu $87 \%$. Dengan gambaran karakteristik responden seperti itu dapat dipahami bahwa pemberdayaan perempuan di Desa Cikunir masih kurang. Dengan tingkat pendidikan yang rendah, ibu tidak mampu untuk mendapatkan pekerjaan yang layak, sehingga sebagian besar dari mereka menggantungkan hidupnya pada pendapatan suami.

Keluarga merupakan subsistem dari masyarakat dan negara yang memiliki struktur sosial serta sistemnya sendiri. Dalam keluarga kehidupan seseorang dimulai, dimana seorang anak mendapat perlindungan dengan nyaman, seorang istri/ibu melakukan tugasnya, mendapatkan haknya, seorang Ayah/suami memberikan kenyamanan, ketentraman, melakukan tugastugasnya sebagai kepala keluarga. Dalam teori struktural fungsional peran masing-masing anggota keluarga sangat ditentukan oleh struktur kekuasaan laki-laki (ayah) sebagai kepala keluarga yang secara hierarkis memiliki kewenangan paling tinggi dalam keputusan-keputusan keluarga. Hierarki dilanjutkan pada perbedaan usia dan jenis kelamin anggota keluarga, misalnya saudara laki-laki memiliki struktur sosial lenih tinggi dibanding saudara perempuan. Relasi yang dibangun seolah-olah laki-laki memiliki kemampuan/kekuasaan/kekuatan lebih besar dibanding anggota keluarga perempuan. (Widaningsih, 2007)

Banyak stereotipe bahkan mitos di masyarakat, misalnya tanggungjawab mutlak terhadap ekonomi keluarga hanya ada ditangan ayah/suami, sementara tanggungjawab domestik melulu tanggungjawab ibu/istri. Faktanya begitu banyak kaum perempuan yang mampu menjadi tulang punggung keluarga, secara mandiri menghidupi keluarganya dan lebih mampu bertahan dalam kesulitan ekonomi keluarga. Tetapi dalam tradisi dibanyak daerah peran permpuan tersebut dalam memperkuat ekonomi keluarga seringkali tidak diperhitungkan dan selalu dianggap sebagai pelengkap saja. Persepsi seperti itu tidak saja mengesampingkan peran perempuan tetapi disisi lain membebani kaum laki-laki. Kesetaraan gender dimaksudkan untuk memberikan keseimbang peran antara laki-laki dan perempuan dalam keluarga maupun masyarakat sehingga tidak ada pelebelan peran-peran milik laki-laki atau perempuan saja. (Widaningsih, 2007)

Peran gender yang tidak seimbang antara laki-laki dan perempuan akan menciptakan suasana yang tidak 
harmonis dan tidak adil bagi keduanya. Peran gender harus dilakukan dalam landasan "kemanusiaan" sebagai manusia yang mempunyai kelebihan dan kelemahan secara kodrati. Peran gender yang harus dimainkan oleh individu dan masyarakat adalah peran yang saling memahami, saling membantu, dan saling menghargai setiap perbedaan yang terdapat pada diri manusia maupun dalam masyarakat tanpa mempertimbangkan perbedaan bentuk tubuh yang berbeda antara laki-laki dan perempuan. Peran gender yang dilakukan oleh masyarakat dulu hingga sekarang ini selalu merujuk

\section{F. Simpulan}

Berdasarkan hasil penelitian diketahui bahwa perspektif gender masyarakat sunda di Desa Cikunir Kecamatan Singaparna Kabupaten Tasikmalaya sebagian besar berperspektif positif. Meskipun demikian tidak dapat dipandang sebelah mata meskipun hanya sebagian kecil yang berperspektif negatif . Penempatan perempuan yang tidak seimbang akan menciptakan ketidakharmonisan dalam membina kehidupan rumah tangga dan masyarakat.

\section{G. Saran}
a. Pasangan Usia Subur (PUS)
1) Suami/Istri hendaknya dapat proaktif dalam mencari informasi tentang gender dapat melalui televisi, radio, koran, tokoh agama atau petugas kesehatan di puskesmas.

pada konsep "patriakhi”, sehingga memunculkan peran gender yang tidak seimbang. Peran yan tidak seimbang tersebut memunculkan ketidakadilan yang dirasakan oleh kaum perempuan. Penempatan perempuan yang tidak seimbang akan menciptakan ketidakharmonisan dalam membina kehidupan rumah tangga dan masyarakat. Selain itu peran gender yang tercipta juga akan membuat kondisi yang keruh, kerana tidak adanya penghargaan, pengertian, dan pemahaman yang merujuk pada aturan yang disepakati oleh kaum laki-laki.(Nurlian \& Daulay)

2) Suami/Istri hendaknya dapat saling menghormati hak dan kewajiban satu dengan yang lainnya. 3) Suami/Istri hendaknya bertanggungjawab bersama-sama dalam membangun keharmonisan dan kesejahteraan keluarga

b. Puskesmas

Puskesmas hendaknya mensosialisasikan isu gender kepada masyarakat serta menyusun program pengarusutamaan gender yang dapat bekerjasama dengan lintas sektor seperti P2TP2A di tingkat Kabupaten sebagai upaya meningkatkan pemahaman masyarakat akan pentingnya program pemberdayaan perempuan dalam membangun kesehatan keluarga. 


\section{H. Daftar Pustaka}

Asriani, D,D., 2010., Kesehatan

Reproduksi Dalam Bingkai

Tradisi Jawa (pengalaman

Perempuan Petani Gunung

Kidul), PKBI DIY, Yogyakarta

Kementrian Pemberdayaaan

Perempuan RI, 2003, Bunga

Rampai Bahan Pembelajaran

Pelatihan Pengarusutamaan

Gender Dalam Proram

Pembangunan Nasional,

Jakarta

Mufidah, CH., 2004, Rekonstruksi

Kesetaraan Gender Dalam

Konteks Sosial Budaya dan

Agama, Desertasi, IAIN Sunan

Ampel Surabaya

Muhammad., H., 2002, Tubuh,

Seksualitas, dan Kedaulatan

Perempuan Bunga Rampai

Pemikiran Ulama Muda, Lkis, Jogjakarta

Nugroho.T., Setiawan.A, 2010, Kesehatan Wanita, Gender dan permasalahannya, Nuha Medika, Bantul

Stalker.,P., 2008, Laporan

Pencapaian Millenium

Development Goals (MDGs)

Indonesia, BAPPEAS dan

UNDP, Jakarta

Urlian, Daulay.,M, Kesetraan

Gender Dalam Pembagian

Kerja Pada Keluarga Petani

Ladang (studi Kasus Analisa

Isu Gender Pada Keluarga

Petani Ladang di Desa Cot

Rambong, Kecamatan Kuala,

Kabupaten Nagan raya, NAD)

Widaningsih, 1., 2007, Relasi

Gender Dalam Keluarga:

Internalisasi ilai-ilai

Kesetraan Dalam Memperkuat

Fungsi Keluarga, Departemen
Pendidikan Provinsi Jawa Barat, Bandung

YPKP, 2013, Perspektif Gender dan HAM dalam Asuhan Kebidanan Komunitas, YPKP, Jakarta 